\title{
PENGARUH LATIHAN STRATEGI MENYERANG MENGGUNAKAN POLA 1-2-1 DAN POLA 2-2 TERHADAP EFEKTIVITAS MENCETAK GOL PADA SISWA EKSTRAKURIKULER FUTSAL MAN 2 SAMARINDA
}

\author{
Julianur, Andri Tria Raharja, Januar Abdilah Santoso \\ Pendidikan Olahraga, Universitas Muhammadiyah Kalimantan \\ Timur \\ Email: julianur@umkt.ac.id
}

\begin{abstract}
Abstrak
Penelitian ini bertujuan untuk mengetahui apakah ada pengaruh latihan strategi menyerang menggunakan pola 1-2-1 dan pola 2-2 terhadap efektivitas mencetak gol pada siswa ekstrakurikuler futsal MAN 2 Samarinda. Penelitian ini bersifat eksperimen lapangan dengan melibatkan dua variable bebas dan satu variable terikat yaitu efektivitas mencetak gol. Populasi penelitian ini adalah keseluruhan siswa ektrakurikuler futsal MAN 2 Samarinda. Sampel penelitian ini sebanyak 20 orang dengan menggunakan machid ordinat, yang dibagi kedalam dua kelompok latihan yaitu kelompok $A$ dengan metode latihan strategi menyerang menggunakan pola 1-21 dan kelompok $B$ dengan metode latihan strategi menyerang menggunakan pola 2-2, masing-masing kelompok terdiri 10 orang. Teknik analisis data diolah dengan menggunakan bantuan komputer melalui program SPSS 21.0. Berdasarkan analisis data diperoleh hasil: (1) Ada pengaruh metode latihan strategi menyerang menggunakan pola 1-2-1 terhadap efektivitas mencetak gol pada siswa ekstrakurikuler futsal MAN 2 Samarinda, terbukti dengan nilai t hitung (to) $=3.096>\mathrm{t}$ tabel $\alpha 0.05=1.734$. (2) Ada pengaruh metode latihan strategi menyerang menggunakan pola 2-2 pada siswa ekstrakurikuler futsal MAN 2 Samarinda, terbukt dengan nilai $t$ hitung (to) $=2.228>\mathrm{t}$-tabel $\alpha 0.05=1.734$. Metode latihan strategi menyerang menggunakan pola 1-2-1 memberikan pengaruh yang lebih baik dibandingkan dengan metode latihan strategi menyerang menggunakan pola 2-2 terhadap efektivitas mencetak gol pada siswa ekstrakurikuler futsal MAN 2 Samarinda.
\end{abstract}

Kata Kunci: strategi menyerang futsal, futsal

\begin{abstract}
This study aims to determine whether there is an effect of attack strategy using 1-2-1 patterns and 2-2 patterns on the effectiveness of scoring goals for MAN 2 Samarinda futsal extracurricular students. This research is a field experiment involving two independent variables and one dependent variable is the goal scoring effectiveness. The population of this study were all MAN 2 Samarinda futsal extracurricular students. The sample of this study was 20 people using machid ordinate, which was divided into two groups of exercises namely group $A$ with the attack method training method using 1-2-1 and group B patterns with the attack strategy training method using a 2-2 pattern, each group consists of 10 people. Data analysis techniques were processed using computer assistance through the SPSS 21.0 program. Based on the data analysis, the results were obtained: (1) There was the influence of the attack strategy training method using the 1-2-1 pattern on the effectiveness of goal scoring in MAN 2
\end{abstract}


Samarinda futsal extracurricular students, as evidenced by $\mathrm{t}$ count (to) $=3.096>\mathrm{t}$ table $\alpha 0.05=1,734$. (2) There is the effect of the attack strategy training method using pattern 2-2 on MAN 2 Samarinda futsal extracurricular students, as evidenced by the value of $t$ arithmetic (to) $=2.228>t$-table $\alpha 0.05=1.734$. The method of attacking training strategies using 1-2-1 patterns has a better effect than the training method of attack strategy using a 2-2 pattern on the effectiveness of scoring goals for MAN 2 Samarinda futsal extracurricular students.

Keywords: futsal attack strategy, futsal

\section{PENDAHULUAN}

Perkembangan olahraga sekarang ini semakin berkembang pesat sesuai dengan perkembangan zaman. Semakin pesat perkembangan zaman turut pula mempengaruhi munculnya jenis olahraga baru, salah satunya adalah olahraga futsal. Pada saat ini, olahraga futsal sudah berkembang dikota-kota besar maupun didaerah. Awal munculnya olahraga futsal di kota-kota besar adalah kebutuhan orang-orang kota untuk melakukan olahraga permainan sepak bola, oleh karena saranan olahraga sepak bola membutuhkan lapangan yang luas maka sebagai solusinya melakukan aktivitas olahraga permainan sepak bola mini yang sering disebut dengan olahraga permainan futsal.

Futsal adalah permainan bola yang dimainkan oleh dua regu, yang masing-masing beranggotakan lima orang.
Tujuannya adalah memasukkan bola ke gawang lawan, dengan memainkan bola dengan kaki. Selain lima pemain utama, setiap regu juga diizinkan memiliki pemain cadangan. Tidak seperti permainan sepak bola dalam ruangan lainnya, lapangan futsal dibatasi garis, bukan net atau papan.

Futsal adalah aktivitas permainan beregu yang dimainkan lima lawan lima orang dalam durasi waktu tertentu yang dimainkan pada lapangan, gawang dan bola yang relatif lebih kecil dari permainan sepak bola yang mensyaratkan kecepatan bergerak, menyenangkan serta aman dimainkan serta tim yang menang adalah tim yang lebih banyak mencetak gol ke gawang lawannya.

Futsal merupakan salah satu cabang olahraga yang banyak digemari dimasyarakat, Seseorang dalam bermain mempunyai tujuan yang tidak sama, ada yang hanya 
sekedar mengisi waktu luang dan ada pula yang melakukannya sebagai olahraga rekreasi atau juga untuk mencapai prestasi yang maksimal, seseorang dituntut harus menguasai teknik-teknik dasar, taktik dan mental bertanding yang baik serta memiliki kemampuan kondisi fisik yang baik. Terlebih lagi saat ini seorang bermain benarbenar dituntut untuk mengikuti perkembangan permainan futsal dengan ditunjang kemampuan fisik yang baik, agar mereka mampu bermain selama pertandingan penuh yaitu 2 × 20 menit. Walaupun lama pertandingannya lebih cepat daripada permainan sepak bola namun permainan bolanya berjalan dengan sangat cepat sehingga menguras banyak tenaga. Oleh kerana itu seorang pemain dituntut untuk melakukan latihan kondisi fisik dengan baik dan benar. Untuk menjadi pemain futsal yang berkualitas dan terampil perlu adanya pembinaanpembinaan yang terarah dan teratur. Ada empat macam kelengkapan yang perlu dimilikli apabila seseorang akan mencapai perstasi yang optimal. Kelengkapan tersebut meliputi: pengembangan fisik, pengembangan teknik, pengembangan mental dan kematangan juara (Sajoto, 1995:7). Dari keempat kelengkapan pokok tersebut, teknik bermain merupakan kelengkapan yang fundamental sebagai dasar bermain disamping pembinaan yang lain.

Dalam permainan futsal, teknik dasar merupakan sesuatu syarat yang wajib dikuasai oleh setiap pemain futsal karena sangat besar pengaruhnya terhadap prestasi. Penguasan tehnik dasar adalah gerakan yang harus dimiliki setiap pemain, sehingga permainan dapat melakukannya dengan baik, adapun tekhnik dasar meliputi: 1) Teknik menyepak dan menghentikan bola (passing and control), 2) Teknik menggiring bola (dribbling), dan 3) Teknik bola dengan kepala (heading). Melihat dari berbagai macam tekhnik dasar yang digunakan dalam permainan futsal tentunya dalam perkembangannya perlu menguasai teknik dasar tersebut menuju ke arah tingkat keterampilan yang lebih baik lagi selain faktor kondisi fisik 
dan taktik yang benar-benar harus

dilatih secara mendalam dan cermat secara ilmiah.

Tujuan permainan futsal adalah bagaimana cara memasukkan bola ke dalam gawang lawan dengan sebanyakbanyaknya dengan mengandalkan kemampuan dan kerjasama tim yang kompak. Dalam permainan futsal semua pemain dalam tim termasuk penjaga gawang akan berusaha untuk menjadi pemain yang multi fungsi kecuali menjadi penjaga gawang.

Ciri-ciri permainan futsal
adalah setiap pemain harus memiliki kemampuan serba bisa (allround), baik sebagai penyerang maupun sebagai pemain belakang, setiap pemain boleh melakukan aksi menyerang dan membuat gol. Tidak memberikan peluang kepada pihak lawan untuk direbut kembali. Dengan demikian maka para pemain harus memiliki keterampilan teknik dasar bermain futsal yang tinggi, kondisi fisik yang prima, kemampuan pengembangan taktik modern dan memiliki kematangan juara. "Sebuah tim akan terus saja digempur apabila tidak menerapkan strategi bertahan sekaligus menyerang. Untuk bisa efektif menghasilkan gol dalam tim tentu dibutuhkan strategi menyerang yang baik. Oleh karena itu perlu melatih strategi menyerang. Beberapa strategi yang dapat dilatih antara lain: latihan strategi menggunakan pola 1-2-1, 2-2, 4-0 dan power play." Justinus Lhaksana (2011:80).

Strategi pola 1-2-1 adalah pola yang menempatkan 1 pemain belakang, 2 pemain tengah dan 1 pemain depan. Saat menyerang 2 pemain tengah bisa membantu serangan, begitu pula sebaliknya saat bertahan. Strategi ini diterapkan saat menghadapi lawan dengan pertahanan yang kuat. Dengan 1 pemain belakang, 2 pemain melebar kesisi lapangan, dan 1 pemain depan disekitar daerah penalty lawan. Saat sudah bola sudah memasuki daerah lawan, akan sangat mudah untuk mengoper bola ke teman, dan mudah untuk melancarkan tembakan kegawang secara bertubi-tubi. Strategi ini juga memiliki kelemahan, yaitu saat serangan dibendung lawan. 
Kemudian lawan melancarkan counter attack,sangat beresiko untuk gawang kita kebobolan, karena hanya menyisakan 1 pemain belakang.

Strategi pola 2-2 adalah pola yang menempatkan 2 pemain belakang dan 2 pemain depan, gunanya untuk penyeimbang pemainan. Saat menyerang 1 pemain belakang bisa membantu serangan. Begitu pula sebaliknya, 1 pemain menyerang bisa membantu pertahanan. Pola strategi ini banyak digunakan saat bermain futsal biasa, atau dapat dikatakan ini pola strategi yang umum.

Strategi ini baik digunakan karena setiap pemain bisa melebar ke empat sudut lapangan yang memainkan bola dengan operan disamping lapangan. Keuntungan strategi 2-2 yaitu, para pemain tidak terlalu menggerombol ditengah lapangan, dengan operan-operan kesamping, itu dapat berdampak pada kelelahan pemain lawan yang mengejar bola, saat pemain depan sudah mulai masuk daerah lawan, pemain belakang bisa maju dan masuk kesisi tengah untuk melakukan tembakan ke gawang.
Akan tetapi, strategi ini memiliki kelemahan yaitu saat lawan berhasil mendapatkan bola, mereka dapat dengan mudah melakukan dribbling dari tengah ke depan daerah penalty, melakukan tembakan langsung dari tengah, atau memberikan umpan langsung kedepan gawang.

Di MAN 2 Samarinda terutama diekstrakurikuler olahraga futsal sangat diminati oleh siswa MAN 2 Samarinda hal ini terbukti dengan banyaknya siswa MAN 2 Samarinda yang mengikuti ekstrakurikuler futsal. Namun, prestasi futsal MAN 2 Samarinda masih minim, dikejuaraan futsal antar pelajar di Samarinda, MAN 2 belum pernah mendapat hasil yang baik.

Berdasarkan pengamatan saya dalam beberapa pertandingan para pemain MAN 2 Samarinda sudah memiliki teknik dasar dan fisik yang cukup baik. Tetapi masih kurang dalam strategi bermain futsal, terutama dalam strategi menyerang. Hal ini dilihat dari minimnya gol MAN 2 Samarinda saat menghadapi lawan dengan pertahanan yang cukup bagus. 
Melihat uraian tersebut di atas, maka peneliti tertarik untuk melihat dan membuktikan tentang penyebab dari seringnya kegagalan mendapat kemenangan disetiap pertandingan. Oleh karena itu dalam penelitian ini peneliti mengambil penelitian dengan judul "Pengaruh Latihan Strategi Menyerang Menggunakan Pola 1-21 Dan Pola 2-2 Terhadap Efektivitas Mencetak Gol Pada Siswa Ektrakurikuler Futsal MAN 2 Samarinda".

\section{METODE}

$$
\begin{array}{lr}
\text { Penelitian ini } & \text { menggunakan } \\
\text { jenis penelitan } & \text { eksperimen } \\
\text { lapangan, dalam } & \text { artian } \\
\text { mengadakan kegiatan } & \text { percobaan } \\
\text { untuk melihat suatu hasil yang akan } \\
\text { menegakan kasual antara variabel } \\
\text { yang akan diteliti, yaitu pengaruh } \\
\text { latihan strategi } \quad \text { menyerang } \\
\text { menggunakan pola } 1-2-1 \text { dan pola } \\
\text { 2-2 terhadap efektivitas mencetak } \\
\text { gol pada siswa ekstrakurikuler MAN } \\
2 \text { Samarinda. }
\end{array}
$$

\section{Populasi dan Sampel}

\section{Populasi}

Populasi merupakan suatu kumpulan atau kelompok induvidu yang dapat diamati oleh anggota populasi itu sendiri atau bagi orang yang mempunyai perhatian terhadapnya. Populasi adalah keseluruhan objek penelitian, dan datanya akan dianalisis (Arikunto, 2006:130). Sedangkan menurut Sugiyono (2009:61) bahwa populasi adalah wilayah generalisasi yang terdiri atas: objek/subjek yang mempunyai kualitas dan karakteristik tertentu yang ditetapkan oleh peneliti untuk dipelajari dan kemudian ditarik kesimpulan.

Berdasarkan pendapat para ahli di atas, maka populasi dari penelitian ini adalah seluruh siswa ekstrakurikuler futsal MAN 2 Samarinda.

\section{Sampel}

Menurut Syarifudin Hidayat (2002:124) bahwa Sampel adalah kelompok kecil yang diamati dan merupakan bagian dari populasi sehingga sifat dan karakteristik populasi juga dimiliki oleh sampel. Menurut Ferguson (dalam Syarifudin Hidayat, 2002: 124) mendefinisikan sampel adalah beberapa bagian kecil atau cuplikan yang di tarik dari populasi. 
Sedangkan menurut Sutrisno Hadi (1989:182) sampel adalah sebagian dari individu yang jumlahnya kurang dari populasi. Berdasarkan pendapat tersebut, maka dapat dikemukakan bahwa sampel adalah wakil yang akan diteliti. Maka yang menjadi sampel pada penelitian ini adalah siswa ekstrakurikuler futsal MAN 2 Samarinda yang berjumlah 20 orang, yang akan diambil secara machid ordinat.

Data tentang pengaruh latihan strategi menyerang menggunakan pola 1-2-1 dan pola 2-2, dan hasil efektivitas gol akan penulis analisis dengan menggunakan alat uji analisis berupa t-test dengan rumus:

1. Statistik deskriptif, memberikan gambaran umum hasil rata-rata standar deviasi dari variable dari kedua kelompok.

2. Statistik inferensial, menguji hipotesis penelitian-penelitian dengan menggunakan uji-t pada taraf signifikan 5\%. Uji-t untuk menghitung perbedaan mean test awal dan test akhir untuk kedua kelompok yang berbeda rumus:

$t=\frac{m d}{\sqrt{\frac{\sum X d^{2}}{n(n-1)}}}$
Keterangan:

$t \quad$ : Statistik perbedaan

md : Mean dari perbedaan pre test dan post test

$\sum x d^{2}$ : Jumlah kuadrat deviasi

n : Jumlah sampel

Perhitungan perbedaan pengaruh kedua

$t=\frac{\overline{x A_{2}}-\overline{x B_{2}}}{\sqrt{\left(\frac{(S d A)+(S d B)^{2}}{n A+n B-2}\right)\left(\frac{1}{n A}+\frac{1}{n B}\right)}}$

Keterangan:

$\overline{x A_{2}}$ : Rata-rata kelompok latihan 1-2-1

$\overline{x B_{2}}$ : Rata-rata kelompok latihan

2-2

SdA : Standart deviasi kelompok 12-1

$S d B$ : Standart deviasi kelompok 22

n : Jumlah sampel

\section{HASIL PENELITIAN}

Data hasil penelitian yang diperoleh yaitu data tes awal dan data tes akhir hasil efektivitas mencetak gol pada kelompok yang diberi latihan strategi menyerang menggunakan pola 1-2-1 dan pola 2-2 pada siswa ekstrakurikuler futsal MAN 2 Samarinda.Kedua 
bentuk latihan yang diberikan bertujuan untuk meningkatkan efektivitas mencetakgol pada saat menyerang.

\section{Analisis Deskriptif Data}

Rangkuman hasil analisis deskriptif data hasil penelitian tercantum dalam tabel 1 berikut ini:

Tabel 1. Hasil analisis deskriptif data tes awal dan tes akhir hasil efektivitas mencetak gol pada latihan strategi menyerang menggunakan pola 1-2-1 (A)

\begin{tabular}{|c|c|c|c|c|}
\hline $\begin{array}{c}\text { Latihan strategj } \\
\text { menverang mengqunakan } \\
\text { polal 1-2-1 }\end{array}$ & $N$ & Mean & $\begin{array}{c}\text { Std. } \\
\text { Deviation }\end{array}$ & Variance \\
\hline Tes awal & 10 & 0,60 & 0,843 & 0,711 \\
\hline Tes akkii & 10 & 2,00 & 2,055 & 4,222 \\
\hline
\end{tabular}

Tabel 1 diatas menunjukan penghitungan rata-rata, simpangan baku, dan varians skor tes awal dan tes akhir hasil efektivitas mencetak gol pada latihan strategi menyerang menggunakan pola 1-2-1. Pada latihan strategi menyerang menggunakan pola 1-2-1 skor tes awal diperoleh rata-rata sebesar 0,60, simpangan baku 0,843 , dan varians 0,711. Sedangkan pada skor tes akhir latihan strategi menyerang menggunakan pola 1-21 diperoleh rata-rata sebesar 2,00, simpangan baku 2,055, dan varians 4,222 .

Tabel 2. Hasil analisis deskriptif data tes awal dan tes akhir hasil efektivitas mencetak gol pada latihan strategi menyerang menggunakan pola 2-2 (B)

\begin{tabular}{|c|c|c|c|c|}
\hline $\begin{array}{c}\text { Lathan strategi menverang } \\
\text { mengugnakan pola } 2 \cdot 2\end{array}$ & $N$ & Mean & $\begin{array}{c}\text { Std. } \\
\text { Deviation }\end{array}$ & Varia \\
\hline Tes awa & 10 & 0,60 & 0,843 & 0,7 \\
\hline Tes akhir & 10 & 1,30 & 1,560 & 2456 \\
\hline
\end{tabular}

Tabel 2 diatas menunjukan perhitungan rata-rata, simpangan baku, dan varians skor tes awal dan tes akhir hasil efektivitas mencetak gol pada latihan strategi menyerang menggunakan pola 2-2. Pada latihan strategi menyerang menggunakan pol 2-2 skor tes awal diperoleh rata-rata sebesar 0,60 , simpangan baku 0,843 , dan varians 0,711 . Sedangkan pada skor tes akhir pada latihan strategi menyerang menggunakan pola 2-2 diperoleh rata-rata sebesar 1,30, simpangan baku 1,567 , dan varians 2,456 .

Uraian tersebut diatas hanyalah merupakan gambaran umum tentang data yang diperoleh dari hasil penelitian dan belum 
menunjukkan hasil penelitian yang sebenarnya.Untuk mengetahui hasil penelitian yang sesungguhnya, maka selanjutnya adalah melakukan pengujian hipotesis.

2. Pengujian Hipotesis

Setelah data deskriptif telah diketahui, maka selanjutnya kita akan melakukan pengujian dan analisis terhadap kedua kelompok data sampel (pengujian dan analisis ini untk mengetahui apakah terdpat perubahan hasil efektivitas mencetak gol yang signifikan dari kedua kelompok sampel. Hasil analisis statistika dapat dilihat pada tabel 3 dibawah ini:

Tabel 3. Hasil penghitungan dan uji signifikansi hasil efektivitas mencetak gol kedua kelompok.

\begin{tabular}{|c|c|c|c|}
\hline Kelomponk & t-hitung & $\begin{array}{c}\text { t-tabel } \\
(0.95 \cdot 18)\end{array}$ & Signifikansi \\
\hline $\begin{array}{c}\text { Latiban strtategi } \\
\text { menyerang } \\
\text { mengaunakan pola 1-2-1 }\end{array}$ & 3,096 & 1,734 & Signifikan \\
\hline $\begin{array}{c}\text { Lathan strtategi } \\
\text { menyerang } \\
\text { mengaunakan pola 2-2 }\end{array}$ & 2,228 & 1,734 & Signifikan \\
\hline
\end{tabular}

Penghitungan dan uji signifikansi hasil efektivitas mencetak gol kedua kelompok sampel dilkukan dengan menggunakan uji signifikansi kesamaan dua rata-rata uji dua pihak yaitu uji t. Dari hasil pengujian tersebut diperoleh bahwa $t$ hitung latihan strategi menyerang menggunakan pola $1-2-1=3,096$ yang lebih besar dari t-tabel pada tingkat kepercayaan atau tarraf signifikansi $\alpha=0,05$ dengan $\mathrm{dk}\left(\mathrm{n}_{1}+\right.$ $\left.\mathrm{n}_{2}-2\right)=18$, harga $\mathrm{t}(0,95)$ dari daftar distribusi t diperoleh 1,734. Kriteria pengujian adalah, terima $\mathrm{H}_{0}$ jika $-t 1-1 / 2 \alpha<t<t 1-1 / 2 \alpha$. Maka t hitung berada pada daerah penolakan $\mathrm{H}_{0}, \quad$ jadi $\mathrm{H}_{0}$ ditolak.Kesimpulannya adalah latihan strategi menyerang menggunakan pola 1-2-1 memberikan pengaruh yang signifikan terhadap hasil efektivitas mencetak gol. Sedangkan dari hasil pengujian kdua diproleh $\mathrm{t}$ hitung latihan strategi menyerang mengunakan pola 2-2 $=2,228$ yang lebih besar dari t tabell pada tingkat kepercayaan atau taraf signifikansi $\alpha=0,05$ dengan $d k\left(n_{1}+n_{2}-2\right)=$ 18, harga $t(0,95)$ dari daftar distribusi t diperoleh 1,734.

Kriteria pngujian adalah, terima $\mathrm{H}_{0}$ jika $\quad-t 1-1 / 2 \alpha<$ $\mathrm{t}<t 1-1 / 2 \alpha$. Maka t hitung berada pada daerah penolakan $\mathrm{H}_{0}$, jadi $\mathrm{H}_{0}$ ditolak.Kesimpulannya adalah latihan strategi menyerang 


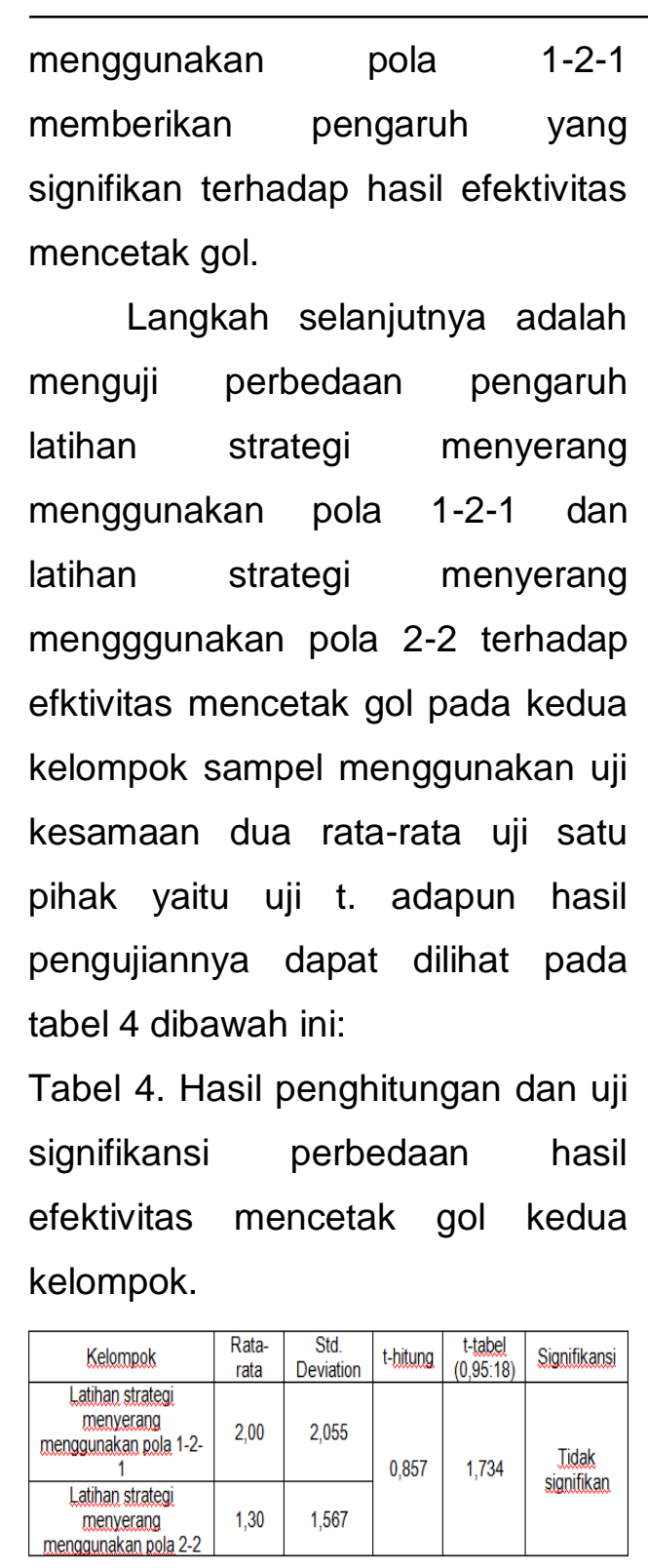

Pada hasil pengujian kedua untuk latihan strategi menyerang menggunakan pola 1-2-1 dan latihan strategi menyerang menggunakan pola 2-2 diperleh $\mathrm{t}$ hitung $=0,857$ lebih kecil dari t tabel pada tingkat kepercayaan atau taraf signifikansi $\alpha=0,05$ dengan $\mathrm{dk}\left(\mathrm{n}_{1}+\right.$ $\left.\mathrm{n}_{2}-2\right)=18$, harga $\mathrm{t}(0,95)$ dari daftar distribusi t diperoleh 1,734. Kriteria pngujian adalah, terima $\mathrm{H}_{0}$ jika $-t 1-1 / 2 \alpha<t<t 1-1 / 2 \alpha$. Maka $t$ hitung berada pada daerah penerimaan $\mathrm{H}_{0}, \quad$ jadi $\mathrm{H}_{0}$ diterima.Kesimpulannya adalah tidak terdapat perbedaan hasil efektivitas mencetak gol yang signifikan antara kelompok latihan strategi menyerang menggunakan pola 1-2-1 dengan kelompok latihan strategi menyerang menggunakan pola 2-2. Dalam hal ini latihan strategi menyerang menggunakan pola 1-2-1 memberikan pengaruh yang sama baiknya dengan latihan strategi menyerang menggunakan pola 2-2 terhadap efektivitas mencetak gol.

\section{PENUTUP \\ Kesimpulan}

Berdasarkan analisis data dan pembahasannya maka penelitian ini dapat disimpulkan sebagai berikut:

1. Latihan strategi menyerang 1-2-1 memberikan pengaruh yang signifikan terhadap efektivitas mencetak gol pada siswa eksttrakurikuler futsal MAN 2 Samarinda. 
2. Latihan strategi menyerang 2-2 memberikan pengaruh yang signifikan terhadap efektivitas mencetak gol pada siswa eksttrakurikuler futsal MAN 2 Samarinda.

Tidak terdapat perbedaan pengaruh yang signifikan antara latihan strategi menyerang menggunakan pola 1-2-1 dan pola 2-2 terhadap efektivitas mencetak gol pada siswa eksttrakurikuler futsal MAN 2 Samarinda.

\section{Saran}

Dengan hasil kesimpulan yang diperoleh, maka saran-saran yang diberikan dalam penelitian ini adalah sebagai berikut:
1. Untuk meningkatkan efektiviitas mencetak gol pada siswa ektrakurikuler futsal MAN 2 Samarinda perlu diberikan latihan strategi menyerang menggunakan pola 1-2-1 dan latihan strategi menyerang menggunakan pola 2-2 dalam aktivitas latihannya.

2. Supaya pembinaan olahraga futsal khususnya pada strategi bermain dalam efektivitas mencetak gol di MAN 2 Samarinda dapat mencapai hasil yang maksimal mapa perlu disarankan kepada pihak sekolah untuk menyiapkan sarana dan prasarana yang memadai terutama yang mendukung kegiatan sswa dalam mengeksplorasikan keterampilannya dalam suatu latihan.

3. Agar kiranya hasil penelitian ini menjadi acuan bagi pembinaan olahraga futsal di sekolah dan menjadi bahan pertimbangan dalam hal memperbaiki koordinasi serta mengembangkan strategi bermain menyerang saat bertanding.

\section{DAFTAR PUSTAKA}

Arikunto, Suharsimi, 2006. Prosedur Penelitian, Jakarta: PT. Rineka Cipta.

Hadi. Sutrisno. 1989. Statistic Jilid III. Yogyakarta: Andi Offset.

Hidayat, Syarifudin. 2002. Metodologi Penelitian, Bandung, Mandar Maju. 
Lhaksana, Justinus. 2011. Taktik dan Strategi Futsal Modern, Jakarta, Be Champion.
Sugiyono, 2013. Metode penelitian Kuantitatif, Kualitatif, dan $R$ \& $D$, Bandung, Alfabeta.

Sajoto. 1995. Pengembangan dan Pembinaan Kekuatan kondisi Fisik Dalam Olahraga. Jakarta: Dahara Prize. 